\title{
Determination of physical and chemical properties of kombucha teas prepared with different herbal teas
}

\author{
Serap KAYISOGLU ${ }^{1 *}$ [D, Fatma COSKUN ${ }^{2}$
}

\begin{abstract}
In this research, kombucha tea was prepared using 5 different tea extracts and physicochemical and sensory analyses were made. The tea extracts used are black tea, green tea, sage, linden and mint, respectively. The prepared tea samples were subjected to fermentation for 14 days. In tea samples, $\mathrm{pH}$, electrical conductivity, water-soluble solid and phenolic components were analyzed before and after fermentation. $\mathrm{pH}$ values decreased by an average of $63 \%$ in all tea samples after fermentation. The electrical conductivity increased in black tea, green tea and mint tea, while sage and linden decreased. Brix values decreased in all tea samples, the most decrease was in black tea. Total amount of phenolic contents of kombucha tea samples decreased excluding mint tea sample. As a result of sensory analysis of tea samples, mint tea got the highest score. As a result of the research, it has been determined that the kombucha tea, which is usually made with black and green tea, can be prepared with teas of different flavors and its consumption can be increased.
\end{abstract}

Keywords: kombucha tea; herbal teas; phenolic contents; sensory evaluation; brix.

Practical Application: Preparation of the kombucha tea by 5 different herbal teas with inoculum kombucha mushrooms.

\section{Introduction}

Kombucha tea is a type of refreshing beverage that is produced both homemade and commercially produced by many companies and is widely consumed in the world. Its consumption is increasing day by day due to the delicious taste, antioxidant properties of tea extracts and beneficial effects of fermentative bacteria which have antioxidant properties. Phenolic substances found in the leaves of tea used in kombucha tea production have also antimicrobial effects on microorganisms such as Aeromonas, Bacillus, Clostridium botulinum, Clostridium perfringens, Enterobacter, Klebsiella, Proteus, Pseudomonas, Shigella, Staphylococcus aureus, Streptococcus (Chung et al., 1998; Coşkun, 2006).

Bacteria and yeasts lead a symbiotic life in the cellulosic film layer where the microorganisms that play a role in the fermentation of kombucha tea are found. Gram negative aerob bacilli, yeasts and lactic acid bacteria in the Acetobacteraceae family were identified in this film layer (Kurtzman et al., 2001; Velićanski et al., 2014). This cellulosic structure, which increases in thickness as fermentation progresses, provides the necessary oxygen for microorganisms (Martínez Leal et al., 2018; Değirmencioğlu et al., 2019). These microorganisms create free phenolics using phenolic compounds in tea leaves, and they create useful fermentation products such as various organic acids, vitamins and minerals for health and also contribute to the sensory properties of the product. The metabolites formed depend on the variety of tea leaves, the variety of microorganisms in symbiotic culture and fermentation conditions (İleri-Büyükoğlu et al., 2010; Jayabalan et al., 2014; Villarreal-Soto et al., 2018).

Kombucha tea is usually prepared from black tea and green tea. This research was carried out considering that it would be beneficial to prepare kombucha tea by sage, linden and mint teas, which are highly valuable for health. In sage, flavones such as apigenin, luteolin, camferol, and quercetin were determined. Carnosol and carnosic acids are also antioxidant phenolic compounds found in sage. Mint (Mentha piperita L.) is one of the commonly consumed herbal teas. The leaves of mint contain phenolic components rosmarinic acid and various flavonoids such as eriocitrin, luteolin and hesperidin. Peppermint has significant antimicrobial and antiviral activities, strong antioxidant and antitumor activities and some antiallergenic potential (McKay \& Blumberg, 2006). Some of the beneficial effects of Kombucha tea are anti-microbial, antioxidant, anti-carcinogenic and antidiabetic properties that have positive effects on stomach ulcers and high cholesterol. It is also recommended for use in the treatment of different diseases such as AIDS, arthritis, atherosclerosis, cancer, constipation, gallbladder diseases, hemorrhoids, hair growth, hypertension and indigestion. It has also been shown to be effective on immune responses and liver detoxification (Chakravorty et al., 2016). Kombucha tea regulates intestinal flora, strengthens cells, helps the body maintain acid-alkaline balance and acts as a natural antibiotic (Kaufmann, 1996). Great attention should be paid in home-made kombucha tea, since pathogenic microorganisms are likely to contaminate the 
tea. Some people consuming homemade tea have dizziness, headache, nausea, and allergic reactions. For this reason, it can lead to contraindications in pregnant and lactating women and should be consumed with caution (Jayabalan et al., 2014). However, as a result of tests carried out by the U.S. Food and Drug Administration, kombucha tea has been reported to be safe for human consumption (Villarreal-Soto et al., 2018).

In this study, black tea, green tea, sage, mint and linden teas were used in making the kombucha tea. The fermentation period was kept for 14 days in making kombucha tea. In tea samples taken before and after fermentation, $\mathrm{pH}$, electrical conductivity, brix, total amount of phenolic substance, color $(\mathrm{L}, \mathrm{a}, \mathrm{b})$ were analyzed and the differences between them was compared. In addition, sensory analysis was performed in the samples at the end of fermentation and the tea samples were listed as sorted according to result of this analysis.

\section{Materials and methods}

\subsection{Materials}

Black tea, green tea, mint, linden, sage, used for making kombucha tea in the research were obtained from local markets in Tekirdağ. Kombucha mushrooms were purchased from the online shopping site via the internet.

\subsection{Preparation and fermentation of herbal teas}

In order to extract the teas, $10 \mathrm{~g}$ of each tea sample which is used as bacterial medium for fermentation was left in 1 liter of boiled water for 15 minutes (Battikh et al., 2012). After extraction, suitable medium was prepared by adding $70 \mathrm{~g} /$ liter of sucrose. The prepared tea samples were transferred to glass jars which were sterilized at $121{ }^{\circ} \mathrm{C}$ for 20 minutes. After we waited until these samples reached room temperature, all samples were inoculated with $7 \mathrm{~g} /$ liter Kombucha mushroom culture. After glass jars were covered with cheesecloth, left to fermentation at $24 \pm 1^{\circ} \mathrm{C}$ and in the dark for 14 days. Tea samples were taken from the incubator at 3-day intervals and analyzes were performed.

\subsection{Physicochemical tests}

Electrical conductivity and $\mathrm{pH}$ values were determined by Martini Instruments MI806 model conductivity meter and the amount of water soluble dry matter was determined by HANNA brand HI 96801 model refractometer. The total amount of phenolic substance was determined using spectrophotometric method (Škerget et al., 2005). L, a, b color measurements of kombucha tea samples were made using Konica Minolta Chorama Meter CR-5.

\subsection{Sensory analysis}

In the sensory evaluation, after the kombucha tea samples were filtered and placed in order, served as light cold to volunteer participants. The hedonic scale was used in the sensory evaluation of kombucha tea samples. The scores given on this scale vary between 1 and 5 ( 5 is very good, 4 is good, 3is acceptable, 2 is not enough, lis bad). The samples were evaluated in terms of taste, smell, color and general acceptability in sensory analysis (Meilgaard et al., 1999).

\subsection{Statistical analysis}

In order to test the differences between the parameters analyzed before and after fermentation in tea samples, two ways analysis of variance (ANOVA) was performed. Significant differences between means were determined by Duncan's multiple range tests at $\mathrm{P}<0.05$ significance level.

\section{Result and discussion}

\section{$3.1 \mathrm{pH}$ values}

A statistically significant difference was observed between the $\mathrm{pH}$ values at the beginning and after fermentation in all tea samples. $\left(\mathrm{F}=133877.6^{* *}\right)$. There was also a significant difference among the initial $\mathrm{pH}$ values of the tea samples $\left(\mathrm{F}=288.9^{* *}\right)$. Initially, the lowest $\mathrm{pH}$ value was measured in black tea sample with 6.86, and the highest $\mathrm{pH}$ value was measured in sage with 7.74. The $\mathrm{pH}$ values of all tea samples decreased after fermentation and there were statistically significant differences among them $\left(\mathrm{F}=460.6^{* *}\right)$. After fermentation, the lowest $\mathrm{pH}$ value was found in black tea with 2.37 and the highest $\mathrm{pH}$ value was found in sage with 3.25 . The decrease in $\mathrm{pH}$ was the highest in kombucha tea prepared with linden tea with $68.0 \%$ (Table 1 ).

It has been stated that the $\mathrm{pH}$ value decreases over time in kombucha tea samples that have been fermented for 10 days using black tea and sucrose sugar, and this decrease is due to organic acids resulting from fermentation (Lončar et al., 2006). As a result of kombucha tea fermentation performed for 2 weeks on sucrose sugar using black tea and green tea, it was stated that the $\mathrm{pH}$ value rapidly decreased from 5 to 3-3.5 (Kallel et al., 2012). Similar results were obtained in this study.

\subsection{Electrical conductivity}

The changes in the electrical conductivities of tea samples at the beginning of fermentation and after were significant statistically. $\left(\mathrm{F}=150.5^{\star *}\right)$. Initially, the electrical conductivity of tea samples differed significantly among themselves $\left(\mathrm{F}=165.9^{* *}\right)$. At the beginning of fermentation, the lowest electrical conductivity value was measured in green tea with a value of $0.590 \mathrm{mS} . \mathrm{cm}^{-1}$, and the highest electrical conductivity value was measured in linden with $1.190 \mathrm{mS} . \mathrm{cm}^{-1}$. The differences among electrical conductivity values of tea samples after fermentation was also statistically significant $\left(\mathrm{F}=412.8^{* *}\right)$. The lowest electrical conductivity value was measured in sage with $0.545 \mathrm{mS} . \mathrm{cm}^{-1}$ and the highest value was measured in black tea with $1.205 \mathrm{mS} . \mathrm{cm}^{-1}$.

Table 1. $\mathrm{pH}$ values of kombucha tea samples at the beginning and after fermentation.

\begin{tabular}{cccc}
\hline $\begin{array}{c}\text { Origin of the } \\
\text { kombucha tea }\end{array}$ & $\begin{array}{c}\text { Beginning of the } \\
\text { fermentation }\end{array}$ & $\begin{array}{c}\text { After the } \\
\text { fermentation }\end{array}$ & $\begin{array}{c}\text { Variation rate } \\
(\%)\end{array}$ \\
\hline Black tea & $6.86 \mathrm{a}$ & $2.37 \mathrm{a}$ & -65.5 \\
Green tea & $6.94 \mathrm{~b}$ & $2.75 \mathrm{c}$ & -60.4 \\
Mint & $7.26 \mathrm{c}$ & $2.75 \mathrm{c}$ & -62.1 \\
Linden & $7.57 \mathrm{~d}$ & $2.42 \mathrm{~b}$ & -68.0 \\
Sage & $7.74 \mathrm{e}$ & $3.25 \mathrm{~d}$ & -58.0 \\
\hline
\end{tabular}


While the electrical conductivity values of black tea, green tea and mint tea increased as a result of fermentation, the electrical conductivity values of linden and sage decreased. The highest increase in electrical conductivity was in black tea with $85.4 \%$ (Table 2).

The electrical conductivity values of foods are widely used in the food industry. For example, electrical conductivity values of water are used to detect contamination in water and to follow microbial growth and metabolic activity (García-Golding et al., 1995; Curda \& Plockova, 1995). There is a high correlation between the electrical conductivity value and the number of lactic acid bacteria. As the lactic acid bacteria increase, the electrical conductivity value increases (Lanzanova et al., 1993).

\subsection{Water soluble solids content (Brix)}

Water soluble dry matter ratios (Brix) were different significantly at the beginning of fermentation and after in all tea varieties $\left(\mathrm{F}=95.5^{* *}\right)$. However, no significant difference was observed among the tea samples in terms of initial Brix values $(\mathrm{F}=1.60)$. At the beginning of the fermentation, the lowest Brix value was found in green tea with $7.40 \%$, the highest Brix value was found in mint tea with $8.10 \%$. After the fermentation Brix values differed significantly in all tea samples $\left(\mathrm{F}=377.6^{* *}\right)$ and the lowest Brix value was 5.45\% in black tea, the highest brix value was $7.60 \%$ in sage. Brix values decreased in all tea samples. The decrease rate was at the highest rate of $28.3 \%$ in black tea (Table 3). Studies have reported that the amount of sucrose decreases linearly in the first 30 days from the beginning of fermentation and then shows a slow decrease (Chen \& Liu, 2000).

\subsection{Total phenolic content}

Total amount of phenolic content in tea samples showed a significant difference at the beginning and after fermentation $\left(\mathrm{F}=176.31^{* *}\right)$. The difference between the tea samples was also important in terms of initial values $\left(\mathrm{F}=788.9^{* *}\right)$ and while the least amount of phenolic content was in sage with the value

Table 2. Electrical conductivity values of kombucha tea samples at the beginning and after fermentation $\left(\mathrm{mS} . \mathrm{cm}^{-1}\right)$.

\begin{tabular}{cccc}
\hline $\begin{array}{c}\text { Origin of the } \\
\text { kombucha tea }\end{array}$ & $\begin{array}{c}\text { Beginning of the } \\
\text { fermentation }\end{array}$ & $\begin{array}{c}\text { After the } \\
\text { fermentation }\end{array}$ & $\begin{array}{c}\text { Variation rate } \\
(\%)\end{array}$ \\
\hline Black tea & $0.650 \mathrm{a}$ & $1.205 \mathrm{~d}$ & 85.4 \\
Green tea & $0.590 \mathrm{a}$ & $0.795 \mathrm{~b}$ & 34.7 \\
Mint & $1.055 \mathrm{~b}$ & $1.00 \mathrm{~d}$ & 13.7 \\
Linden & $1.190 \mathrm{c}$ & $1.075 \mathrm{c}$ & -9.7 \\
Sage & $0.625 \mathrm{a}$ & $0.545 \mathrm{a}$ & -12.8 \\
\hline
\end{tabular}

Table 3. Brix values of kombucha tea samples at the beginning and after fermentation.

\begin{tabular}{cccc}
\hline $\begin{array}{c}\text { Origin of the } \\
\text { kombucha tea }\end{array}$ & $\begin{array}{c}\text { Beginning of the } \\
\text { fermentation }\end{array}$ & $\begin{array}{c}\text { After the } \\
\text { fermentation }\end{array}$ & $\begin{array}{c}\text { Variation rate } \\
(\%)\end{array}$ \\
\hline Black tea & 7.60 & $5.45 \mathrm{a}$ & -28.3 \\
Green tea & 7.40 & $6.75 \mathrm{c}$ & -8.8 \\
Mint & 8.10 & $7.60 \mathrm{e}$ & -6.2 \\
Linden & 7.60 & $6.60 \mathrm{~b}$ & -13.2 \\
Sage & 7.50 & $7.05 \mathrm{~d}$ & -6.0 \\
\hline
\end{tabular}

of $22.78 \mathrm{mg} \mathrm{GAE} /$ liter, it was in mint tea with the highest $175.02 \mathrm{mg}$ GAE/liter. Significant differences were observed between the tea samples in terms of the amount of phenolic content after fermentation $\left(\mathrm{F}=2493.3^{* *}\right)$. The lowest phenolic content was measured in sage with a value of $2.54 \mathrm{mg} \mathrm{GAE} / \mathrm{liter}$, and the highest value was measured in peppermint tea with $189.55 \mathrm{mg} \mathrm{GAE} / \mathrm{liter}$. The amount of phenolic content increased only $8.3 \%$ in mint tea after fermentation. It decreased in all other tea samples. The biggest decline was in sage, with $88.8 \%$ (Table 4 ).

Chu \& Chen (2006) stated that the phenolic content of the kombucha tea made with black tea (4 g/L black tea, $10 \%$ sucrose, 15 days fermentation period) increased linearly throughout the fermentation period. In addition, Yang et al. (2018) showed that fermentation increases the total phenolic content in vegetablefruit fermented beverages. The amount of phenolic substance was determined by the Folin-Ciocalteu method of Kombucha samples in the fermentation performed for 14 days using black tea and green tea and sucrose sugar. Enzymes found in yeast and bacteria break down complex polyphenols, so the kombucha tea contains more phenolic contents than black and green tea (Bhattacharya et al., 2013). However, some researchers have noted that during fermentation, enzymes in yeast and bacteria biodegrade polyphenols, and as a result, total amount of phenolic content drops (Jayabalan et al., 2007). Also, the use of phenolic compounds during fermentation of kombucha tea mushrooms reduces total amount of phenolic content (Amarasinghe et al., 2018).

\subsection{Color parameters}

$\mathrm{L}$ values at the beginning of fermentation were statistically different in all tea samples $\left(\mathrm{F}=117211.7^{* *}\right)$. The same result was seen after fermentation $\left(\mathrm{F}=917555.6^{* *}\right)$. L value of black tea before and after fermentation was lower than other tea samples. $L$ values of the tea samples differed significantly after fermentation $\left(\mathrm{F}=774.8^{* *}\right)$. When a and $\mathrm{b}$ values are examined, it is observed that there are statistical results similar to $L$ values. All color parameters were statistically significantly different among themselves and after fermentation. The decrease in $\mathrm{b}$ values was more prominent after fermentation (Table 5). Tarhan (2017) determined that a (rednessgreenness) values and $\mathrm{b}$ (yellowness-blueness) values decreased over time due to fermentation of Kombucha tea samples belonging to all carbon sources and the amount of reduction in black tea was higher than other fruit teas.

\subsection{Sensory test}

In the sensory evaluation of kombucha tea samples, flavor, smell, color, general acceptability parameters were used. In terms

Table 4. Total amount of phenolic content of kombucha tea samples at the beginning and after fermentation (mg GAE/liter).

\begin{tabular}{cccc}
\hline $\begin{array}{c}\text { Origin of the } \\
\text { kombucha tea }\end{array}$ & $\begin{array}{c}\text { Beginning of the } \\
\text { fermentation }\end{array}$ & $\begin{array}{c}\text { After the } \\
\text { fermentation }\end{array}$ & $\begin{array}{c}\text { Variation rate } \\
(\%)\end{array}$ \\
\hline Black tea & $95.03 \mathrm{~b}$ & $66.30 \mathrm{c}$ & -30.2 \\
Green tea & $160.40 \mathrm{c}$ & $116.79 \mathrm{~d}$ & -27.2 \\
Mint & $175.02 \mathrm{~d}$ & $189.55 \mathrm{e}$ & 8.3 \\
Linden & $26.52 \mathrm{a}$ & $16.06 \mathrm{~b}$ & -39.4 \\
Sage & $22.78 \mathrm{a}$ & $2.54 \mathrm{a}$ & -88.8 \\
\hline
\end{tabular}


Table 5. Color parameters of kombucha tea samples.

\begin{tabular}{|c|c|c|c|c|c|c|}
\hline \multirow{2}{*}{$\begin{array}{l}\text { Origin of the } \\
\text { kombucha tea }\end{array}$} & \multicolumn{3}{|c|}{$\begin{array}{l}\text { Beginning of the } \\
\text { fermentation }\end{array}$} & \multicolumn{3}{|c|}{ After the fermentation } \\
\hline & $\mathrm{L}$ & $\mathrm{a}$ & $\mathrm{b}$ & $\mathrm{L}$ & $\mathrm{a}$ & $\mathrm{b}$ \\
\hline Black tea & $59.29 \mathrm{a}$ & $22.22 \mathrm{e}$ & $68.72 \mathrm{e}$ & $68.79 \mathrm{a}$ & $10.05 \mathrm{e}$ & $58.98 \mathrm{e}$ \\
\hline Green & $80.57 \mathrm{c}$ & $5.33 \mathrm{~d}$ & $57.40 \mathrm{c}$ & $80.22 \mathrm{c}$ & $3.54 \mathrm{~d}$ & $37.17 \mathrm{c}$ \\
\hline Mint & $78.77 \mathrm{~b}$ & $1.06 \mathrm{c}$ & $63.75 \mathrm{~d}$ & $72.76 \mathrm{~b}$ & $2.57 \mathrm{c}$ & $57.86 \mathrm{~d}$ \\
\hline Linden & $88.44 \mathrm{e}$ & $-0.68 b$ & $32.12 \mathrm{~b}$ & $83.69 \mathrm{~d}$ & $1.23 \mathrm{~b}$ & $21.21 \mathrm{~b}$ \\
\hline Sage & $87.53 \mathrm{~d}$ & $-1.85 \mathrm{a}$ & $27.01 \mathrm{a}$ & $90.35 \mathrm{e}$ & $0.09 \mathrm{a}$ & $19.08 \mathrm{a}$ \\
\hline
\end{tabular}

Table 6. Scores of sensory tests of kombucha tea samples.

\begin{tabular}{ccllc}
\hline $\begin{array}{c}\text { Origin of the } \\
\text { Kombucha tea }\end{array}$ & Taste & Smell & Color & $\begin{array}{c}\text { General } \\
\text { acceptability }\end{array}$ \\
\hline Black tea & $2.05 \mathrm{a} . \mathrm{b}$ & $1.79 \mathrm{a}$ & $2.89 \mathrm{a} . \mathrm{b}$ & $2.24 \mathrm{a}$ \\
Green tea & $2.74 \mathrm{~b} . \mathrm{c}$ & $2.58 \mathrm{a} . \mathrm{b}$ & $3.58 \mathrm{c}$ & $2.98 \mathrm{~b}$ \\
Mint & $3.95 \mathrm{~d}$ & $3.47 \mathrm{c}$ & $4.05 \mathrm{c}$ & $3.82 \mathrm{c}$ \\
Linden & $1.58 \mathrm{a}$ & $2.16 \mathrm{a}$ & $2.58 \mathrm{a}$ & $2.10 \mathrm{a}$ \\
Sage & $3.21 \mathrm{c}$ & $3.00 \mathrm{~b} . \mathrm{c}$ & $3.42 \mathrm{~b} . \mathrm{c}$ & $3.21 \mathrm{~b}$ \\
\hline
\end{tabular}

of all sensory parameters evaluated, statistically significant differences were observed among Kombucha tea samples observed $F$ values of taste, smell, color and general acceptability of tea samples were $13.66^{\star *}, 5.54^{\star *}, 6.78^{\star *}$ and 15.26 , respectively. In terms of taste, mint tea has the highest score with 3.95 points, while linden tea has the lowest score with 1.58 points. In the evaluation of smell, mint tea received the highest score with 3.47, while black tea received the lowest score with 1.79 points. In color evaluation, as in odor evaluation, mint tea got the highest score with 4.05 points, while linden tea got the lowest score with 2.58 points. In sensory evaluation, mint tea received the highest score with 3.82 points, while the lowest score was linden tea with 2.10 points. When all parameters were taken into account in sensory tests, it was seen that mint tea had the highest scores and linden tea has the lowest scores (Table 6).

As fermentation progresses, the taste of kombucha tea turns from a delightful fruity, sour and frothy flavor to a light vinegarlike flavor, thereby increasing the consumer acceptability of the flavor and other sensory aspects of the drink (Marsh et al., 2014).

\section{Conclusions}

In this study, as well as Kombucha tea prepared with black tea and green tea, which are commonly consumed, sensory analyzes were made with physicochemical tests by adding Kombucha teas prepared with mint, linden and sage. It is possible to summarize the results obtained from the research as follows:

- While the $\mathrm{pH}$ and Brix values of all tea samples decreased during the fermentation process, their electrical conductivity increased;

- At the end of fermentation, the increase in phenolic content was observed in mint tea. Total phenolic content decreased in other tea samples;

- The color properties of all tea samples have changed significantly;
- Mint tea received the highest score in sensory evaluation. Linden tea has the lowest score. It is possible to say that this is due to the increased acidity of linden tea after fermentation.

As a result of this study, it was determined that the Kombucha tea prepared with Mint was liked more than the black and green teas commonly used in the preparation of Kombucha tea. That's why, In order to increase the consumption of Kombucha tea, it is recommended to be used in traditional teas such as black and green teas as well as teas with different flavors and smell when preparing Kombucha tea.

\section{References}

Amarasinghe, H., Weerakkody, N. S., \& Waisundara, V. Y. (2018). Evaluation of physicochemical properties and antioxidant activities of kombucha "Tea Fungus" during extended periods of fermentation. Food Science \& Nutrition, 6(3), 659-665. http://dx.doi.org/10.1002/ fsn3.605. PMid:29876117.

Battikh, H., Bakhrouf, A., \& Ammar, E. (2012). Antimicrobial effect of kombucha analogues. Food Science and Technology, 47(1), 71-77.

Bhattacharya, S., Gachhui, R., \& Sil, P. (2013). Effect of kombucha, a fermented black tea in attenuating oxidative stress mediated tissue damage in alloxan induced diabetic rats. Food and Chemical Toxicology, 60, 328-340. http://dx.doi.org/10.1016/j.fct.2013.07.051. PMid:23907022.

Chakravorty, S., Bhattacharya, S., Chatzinotas, A., Chakraborty, W., Bhattacharya, D., \& Gachhui, R. (2016). Kombucha tea fermentation: microbial and biochemical dynamics. International Journal of Food Microbiology, 220, 63-72. http://dx.doi.org/10.1016/j. ijfoodmicro.2015.12.015. PMid:26796581.

Chen, C., \& Liu, B. Y. (2000). Changes in major components of tea fungus metabolites during prolonged fermentation. Journal of Applied Microbiology, 89(5), 834-839. http://dx.doi.org/10.1046/j.13652672.2000.01188.x. PMid:11119158.

Chu, S. C., \& Chen, C. (2006). Effects of origins and fermentation time on the antioxidant activities of kombucha. Food Chemistry, 98(3), 502-507. http://dx.doi.org/10.1016/j.foodchem.2005.05.080.

Chung, K. T., Wei, C. I., \& Johnson, M. G. (1998). Are tannins a double-edged sword in biology and health? Trends in Food Science \& Technology, 9(4), 168-175. http://dx.doi.org/10.1016/S09242244(98)00028-4.

Coşkun, F. (2006). G 1 dalarda bulunan do ğ al koruyucular. Gıda Teknolojileri Elektronik Dergisi, 2006(2), 27-33.

Curda, I., \& Plockova, M. (1995). Impedance measurement of growth of lactic acid bacteria in dairy cultures with honey addition. International Dairy Journal, 5(7), 727-733. http://dx.doi.org/10.1016/09586946(94)00038-Q.

Değirmencioğlu, N., Yıldız, E., Şahan, Y., Güldaş, M., \& Gürbüz, O. (2019). Fermentasyon süresinin kombu çayi mikrobiyotasi ve canlilik oranlari üzerine etkileri. Akademik Gıda, 17(2), 200-211. http:// dx.doi.org/10.24323/akademik-gida.613567.

García-Golding, F., Giallorenzo, M., Moreno, N., \& Chang, V. (1995). Sensor for determining the water content of oil-in-water emülsion by specific admittance measurement. Sensors and Actuators, 46-47(1-3), 337-341. http://dx.doi.org/10.1016/0924-4247(94)00917-7.

İleri-Büyükoğlu, T., Taşçı, F., \& Şahindokuyucu, F. (2010). Kombucha ve sağlik üzerine etkileri. Uludag University Journal of the Faculty of Veterinary Medicine, 29(1), 69-76. 
Jayabalan, R., Malbaša, R. V., Lončar, E. S., Vitas, J. S., \& Sathishkumar, M. (2014). A review on kombucha tea-microbiology, composition, fermentation, beneficial effects, toxicity, and tea fungus. Comprehensive Reviews in Food Science and Food Safety, 13(4), 538-550. http:// dx.doi.org/10.1111/1541-4337.12073.

Jayabalan, R., Marimuthu, S., \& Swaminathan, K. (2007). Changes in content of organic acids and tea polyphenols during kombucha tea fermentation. Food Chemistry, 102(1), 392-398. http://dx.doi. org/10.1016/j.foodchem.2006.05.032.

Kallel, L., Desseaux, V., Hamdi, M., Stocker, P., \& Ajandouz, E. H. (2012). Insights into the fermentation biochemistry of Kombucha teas and potential impacts of Kombucha drinking on starch digestion. Food Research International, 49(1), 226-232. http://dx.doi.org/10.1016/j. foodres.2012.08.018.

Kaufmann, K. (Ed.). (1996). Kombucha rediscovered. Canada: Alive Books.

Kurtzman, C. P., Robnett, C. J., \& Basehoar-Powers, E. (2001). Zygosaccharomyces kombuchaensis, a new ascosporogenous yeast from "Kombucha tea." FEMS Yeast Research, 1(2), 133138. http://dx.doi.org/10.1111/j.1567-1364.2001.tb00024.x. PMid:12702358.

Lanzanova, M., Mucchetti, G., \& Neviani, E. (1993). Analysis of conductance changes as a growth index of lactic acid bacteria in milk. Journal of Dairy Science, 76(1), 20-28. http://dx.doi.org/10.3168/jds. S0022-0302(93)77319-1. PMid:8436674.

Lončar, E., Djurić, M., Malbaša, R., Kolarov, L., \& Klašnja, M. (2006). Influence of working conditions upon kombucha conducted fermentation of black tea. Food and Bioproducts Processing, 84(3), 186-192. http://dx.doi.org/10.1205/fbp.04306.

Marsh, A. J., O’Sullivan, O., Hill, C., Ross, R. P., \& Cotter, P. D. (2014). Sequence-based analysis of the bacterial and fungal compositions of multiple kombucha (tea fungus) samples. Food Microbiology, 38, 171-178. http://dx.doi.org/10.1016/j. fm.2013.09.003. PMid:24290641.
Martínez Leal, J., Valenzuela Suárez, L., Jayabalan, R., Huerta Oros, J., \& Escalante-Aburto, A. (2018). A review on health benefits of kombucha nutritional compounds and metabolites. CYTA: Journal of Food, 16(1), 390-399. http://dx.doi.org/10.1080/19476337.2017.1410499.

McKay, D. L., \& Blumberg, J. B. (2006). A review of the bioactivity and potential health benefits of peppermint tea (Mentha piperita L.). Phytotherapy Research, 20(8), 619-633. http://dx.doi.org/10.1002/ ptr.1936. PMid:16767798.

Meilgaard, M. C., Giville, G. V., \& Carr, B. T. (1999). The spectrum descriptive analysis method in sensory evaluation techniques. In M. C. Meilgaard, G. V. Giville \& B. T. Carr (Eds.), Sensory evaluation of techniques (3rd ed., Chap. 11, pp. 189-254). Boca Raton: CRC Press.

Škerget, M., Kotnık, P., Hadolın, M., Hraš, A. R., Sımonıć, M., \& Knez, Ź. (2005). Phenols, proanthocyanidins, flavones and flavonols in some plant materials and their antioxidant activities. Food Chemistry, 89(2), 191-198. http://dx.doi.org/10.1016/j.foodchem.2004.02.025.

Tarhan, K. (2017). Kombucha çayi üretiminde farkli substrat kaynaklarinin kullanimi. Turkey: Akdeniz Üniversitesi.

Velićanski, A. S., Cvetković, D. D., Tumbas Šaponjac, V. T., \& Vulić, J. J. (2014). Antioxidant and antibacterial activity of the beverage obtained by fermentation of sweetened lemon balm (Melissa officinalis L.) tea with symbiotic consortium of bacteria and yeasts. Food Technology and Biotechnology, 52(4), 420-429. http://dx.doi. org/10.17113/ftb.52.04.14.3611. PMid:27904315.

Villarreal-Soto, S. A., Beaufort, S., Bouajila, J., Souchard, J. P., \& Taillandier, P. (2018). Understanding kombucha tea fermentation: a review. Journal of Food Science, 83(3), 580-588. http://dx.doi. org/10.1111/1750-3841.14068. PMid:29508944.

Yang, X., Zhou, J., Fan, L., Qin, Z., Chen, Q., \& Zhao, L. (2018). Antioxidant properties of a vegetable-fruit beverage fermented with two Lactobacillus plantarum strains. Food Science and Biotechnology, 27(6), 1719-1726. http://dx.doi.org/10.1007/s10068-018-0411-4. PMid:30483436. 